\title{
Provas de capacidade científica e aptidão pedagógica
}

\section{As condicionantes demográficas e a evolução do emprego até ao final do milénio na Região de Viseu}

Sob orientação do Professor Doutor Manuel Nazareth, e para efeitos do art. ${ }^{\circ} 29 .^{\circ}$ do Estatuto da Carreira Docente da UCP, realizou Provas de Capacidade Científica e Aptidão Pedagógica, a Docente do Instituto Universitário de Desenvolvimento e Promoção Social, Maria Cristina Sousa Gomes, Licenciada em Sociologia pela Universidade de Évora.

O trabalho de síntese apresentado teve como tema "As Condicionantes Demográficas e a Evolução do Emprego até ao Final do Milénio na Região de Viseu". Ao longo do mesmo, ressaltam as grandes linhas e tendências da evolução desta última década em Viseu, considerando as profundas alterações da dinâmica populacional e os desafios que até ao final do milénio se poderão colocar, vistos numa óptica demográfica, mas pensando nas suas repercussões alargadas ao emprego. Por seu turno, o relatório da lição versou o tema "O conceito de Qualificação".

Foram arguentes dos referidos trabalhos, respectivamente, o Prof. Doutor Manuel Nazareth e o Prof. Doutor Alberto Martinho.

A candidata foi aprovada por unanimidade com a classificação de Muito Bom.

\section{Associação de apoio ao Instituto Universitário de Desenvolvimento e Promoção Social}

Desde a criação da Licenciatura em Gestão e Desenvolvimento Social, tem vindo a verificar-se uma forte dinâmica entre o Instituto Universitário de Desenvolvimento e Promoção Social (I.U.D.P.S.) e os agentes económicos e sociais da área onde nos inserimos.

No sentido de aprofundar esta colaboração, foi criada a Associação de Apoio ao Instituto Universitário de Desenvolvimento e Promoção Social (A.I.U.D.P.S.). Trata-se de uma Associação científica e tecnológica, sem fins lucrativos, e de natureza privada.

A A.I.U.D.P.S. tem em vista proporcionar apoio tanto à instalação e funcionamento do I.U.D.P.S., como ao seu relacionamento com a comunidade em que se insere, particularmente mediante a colaboração com empresas, autarquias, cooperativas, associações e outros organismos públicos.

De acordo com o n..$^{\circ} 2$ do artigo $2 .^{\circ}$ dos Estatutos da A.I.U.D.P.S.e no âmbito das actividades decorrentes do objecto anteriormente expresso,cabe a esta Associação:

a) Apoiar as acções de formação, aperfeiçoamento e divulgação técnica e científica promovidas pelo I.U.D.P.S; 